
Abstracta Iranica
Abstracta Iranica
Revue bibliographique pour le domaine irano-aryen
Volume 27 | 2006
Comptes rendus des publications de 2004

\section{«Loi et sanctuaire à Jérusalem au retour de l'exil ». Transeuphratène, 28 (2004), pp. 91-115.}

\title{
Astrid Nunn
}

\section{(2) OpenEdition}

1 Journals

\section{Édition électronique}

URL : http://journals.openedition.org/abstractairanica/5712

DOI : $10.4000 /$ abstractairanica. 5712

ISSN : 1961-960X

Éditeur :

CNRS (UMR 7528 Mondes iraniens et indiens), Éditions de l'IFRI

\section{Édition imprimée}

Date de publication : 15 mai 2006

ISSN : 0240-8910

\section{Référence électronique}

Astrid Nunn, « «Loi et sanctuaire à Jérusalem au retour de l'exil ». Transeuphratène, 28 (2004), pp. 91-115. », Abstracta Iranica [En ligne], Volume 27 | 2006, document 76, mis en ligne le 02 janvier 2007, consulté le 25 septembre 2020. URL : http://journals.openedition.org/abstractairanica/5712 ; DOI : https://doi.org/10.4000/abstractairanica.5712

Ce document a été généré automatiquement le 25 septembre 2020.

Tous droits réservés 


\section{« Loi et sanctuaire à Jérusalem au retour de l'exil ». Transeuphratène, 28 (2004), pp. 91-115.}

\section{Astrid Nunn}

1 L'A. rassemble des textes au sujet du droit et de la justice dans la perspective du retour de l'exil. Le respect de la loi y est équivalent au respect du sabbat. Au retour de l'exil, le sabbat ne pourra plus être profané et il sera un signe de l'alliance entre Dieu et son peuple. Cette conception permit aux étrangers et aux eunuques d'intégrer la communauté. Ainsi le sabbat joue-t-il un rôle primordial pour justifier l'accession de l'étranger au temple. La reconstitution du temple et la reprise du culte au retour de l'exil occupent une place centrale dans le livre d'Esdras. Dans ce contexte la célébration de la Pâque, qui correspond à un rétablissement du culte de Dieu, joue un rôle important. Pour résoudre le problème épineux des mariages mixtes, les femmes étrangères devront être renvoyées.

\section{INDEX}

Thèmes : 3.2.1. Elam

\section{AUTEURS}

\section{ASTRID NUNN}

Université de Munich 